\title{
A Study of Bacterial Antibiotic Resistance in Four Major Waterways in a Taiwanese City
}

\author{
Shao-Chun Lin ${ }^{1 *}$, Lih-Yau Song ${ }^{2}$ \\ ${ }^{1}$ Group of Sustainable Environmental Design, Institute of Design, National Taipei University of Technology, \\ No. 1, Sec. 3, Zhongxiao E. Rd., Daan Dist., Taipei, Taiwan, R.O.C. \\ ${ }^{2}$ Department of Architecture, National Taipei University of Technology, Taipei, Taiwan, R.O.C.
}

Received: 22 October 2016

Accepted: 5 December 2016

\begin{abstract}
This study tested water samples from four major waterways (Luchuan Canal, Liuchuan Canal, Meichuan Canal, and Mayuantou River) in the center of Taichung, Taiwan, so as to know the viable count of Gram-negative bacteria (VCGB), bacterial resistance patterns, and drug-resistant strains. The samples were collected from the upper, middle, and lower reaches of the waterways, and spread on the MacConkey (MAC) agar plates without antibiotics and with ampicillin (Ap), kanamycin $(\mathrm{Km})$, or tetracycline $(\mathrm{Tc})$. The colonies formed (CFU) were calculated, the colony appearance was observed, and the drug resistance patterns were recorded. Results showed that VCGB in Luchuan Canal, Liuchuan Canal, Meichuan Canal, and Mayuantou River ranged from 12,200 to $56,600 \mathrm{CFU} / \mathrm{ml}, 6,760$ to $44,400 \mathrm{CFU} / \mathrm{ml}, 11,200$ to $21,800 \mathrm{CFU} / \mathrm{ml}$, and 6,800 to $54,800 \mathrm{CFU} / \mathrm{ml}$, respectively. The lactose-fermenting intestinal bacteria (LFIB) accounted for $11.6 \%$ to $81.8 \%$ of the VCGB. In addition, the drug-resistant microorganisms exist in waters universally. The strains resistant to the aforesaid three antibiotics were identified as Escherichia coli, Klebsiella, Providencia stuwartii, and Aeromonas. A lot of untreated effluent might be discharged into the rivers flowing across Taichung, seriously threatening human health. The findings highlight the importance of building sewage disposal systems.
\end{abstract}

Keywords: antibiotic resistance, Gram-negative bacteria, lactose-fermenting intestinal bacteria, river

\section{Introduction}

The elements of aquatic environment are water, space, and the surroundings. The "open" water course flowing across a city not only regulates the temperature and drainage rate of the entire city and beautifies the environment, but also imbues the city with particular

*e-mail: gene5220@hotmail.com scenes. The organisms in the water area are a factor that links an aquatic environment with human life, and the complexity of the organisms is affected by nature and human factor.

Taichung is the largest city in central Taiwan. Compared to other cities in Taiwan, Taichung has more abundant hydrological resources. Among the multiple waterways running through the city, Luchuan Canal, Liuchuan Canal, Meichuan Canal, and Mayuantou River are known as the four major rivers (Fig. 1). Taichung's climate is more 


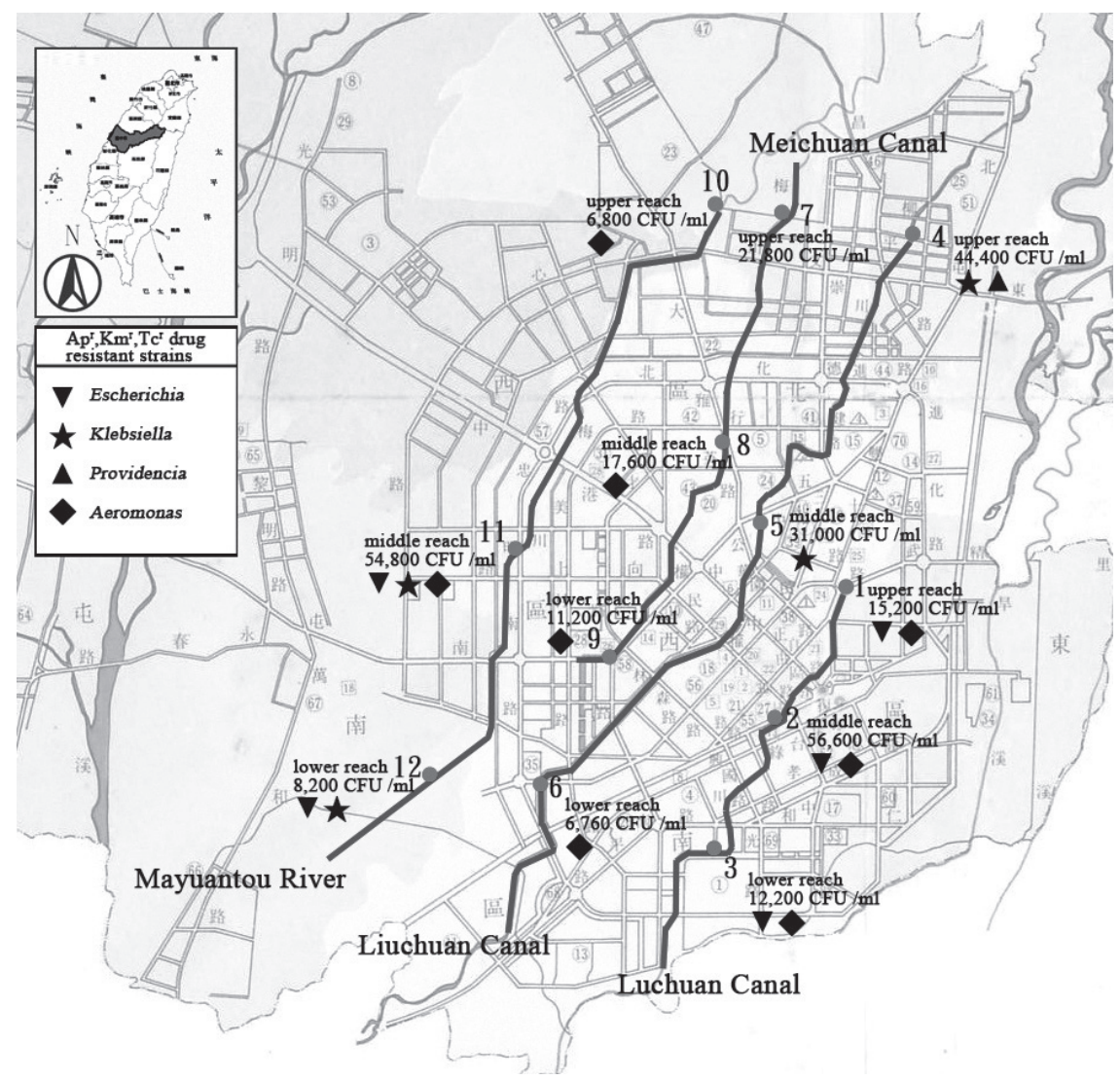

Fig. 1. Types of colony appearance and antibiotic resistance patterns of LFIB in various reaches of waterways. Map of four major rivers in Taichung. Twelve stations (1-12) for sampling water are located on the map. Each station includes the number of VCGB and bacteria strain(s) resistant to Ap, Km, and Tc.

comfortable as regulated by these rivers. The Luchuan Canal at the city center is called the "eternal stream" by the populace. Its overall length is about $10 \mathrm{~km}$, the average bottom slope is $0.76 \%$, and the catchment area is 566.4 ha [1]. Liuchuan Canal is so-named for the weeping willows along its banks. The overall length of Liuchuan Canal is $27.2 \mathrm{~km}$, the average bottom slope is $0.75 \%$, and the upstream catchment area is about 422 ha [1-2]. Meichuan Canal is located in Taichung basin. Belonging to the Wu River system, it is a branch of Liuchuan Canal [3]. The Mayuantou River was so-named because it flows through "Mayuantou," the origin of a hemp farm [4]. The Mayuantou flows through Taichung's urban area and into the Jiuhan River [5]. As a result of urbanization, factory and domestic wastewater is easier to drain into the water area, causing pollution, curve cut-off of river course, and the river course deepening or widening [6]. These four waterways - except for the Mayuantou are heavily polluted [7].

Antibiotics are quite effective bactericides. However, the massive and improper use of antibiotics has resulted in ubiquitous drug-resistant bacteria, and the drug resistance grows successively. Many reports have studied drugresistant bacteria in hospitals, farms, and fish farms where antibiotics are used in large quantities [8-9]. However, drug-resistant bacteria are also widespread in aquatic environments [10].
The coliform group, belonging to Gram-negative bacteria, is often detected in the environment polluted by human or animal excreta. Escherichia coli and the coliform group are the most extensively used index microorganisms for inspecting the sanitary quality of food and water [11]. In the MacConkey (MAC) culture medium, the Gramnegative bacilli colony with lactose fermentability (e.g., $E$. coli and coliform) is red, but they cannot ferment lactose.

In this study the water samples were collected from the four major waterways in the city of Taichung (Luchuan Canal, Liuchuan Canal, Meichuan Canal, and Mayuantou River) cultured in MAC culture medium, with bacterial content, bacterial resistance pattern, and drug-resistant strains calculated. The findings show that drug-resistant intestinal bacteria are ubiquitous in these urban aquatic environments.

\section{Materials and Methods}

\section{Collection of Water Samples}

The water samples were collected by a home-made water collector, which was a $1,000 \mathrm{ml}$ clean plastic measuring cup. It was sterilized by UV irradiation and put in an aseptic plastic bag until use. For collecting water samples, the cup was tied with a $5 \mathrm{~m}$ string through a hole 
punctuated near the rim, and the string was rolled up by a winder, without touching the inside of water collector during the operation. On the selected river embankment or bridge, the winder was rolled to lower the cup into the water slowly, when the water sample flowed into the cup, the winder rolled up the string and the water sample was obtained. Afterward, the water sample was poured into a sterilized screw-capped glass test tube immediately and taken back to the laboratory for analysis. The samples were collected in August 2015.

\section{Operation Procedure}

The $\mathrm{pH}$ value was measured for the water samples by a $\mathrm{pH}$ meter. The sample, diluted with physiological saline solution by 10 -fold series to $10^{-5}$, and 50 or $100 \mu \mathrm{l}$ was spread on the MAC agar without and with ampicillin (Ap), kanamycin $(\mathrm{Km})$, or tetracycline $(\mathrm{Tc})$. The composition of MAC was $(\mathrm{g} / \mathrm{L})$ : pancreatic digest of gelatin $17.0 \mathrm{~g}$, peptones $3.0 \mathrm{~g}$, lactose $10.0 \mathrm{~g}$, bile salts $1.5 \mathrm{~g}$, sodium chloride $5.0 \mathrm{~g}$, agar $13.5 \mathrm{~g}$, neutral red $0.03 \mathrm{~g}$, crystal violet $0.001 \mathrm{~g}$, and final $\mathrm{pH} \sim 7.1$. The final concen- trations of Ap, Km, and Tc antibiotics were 100, 50, and $15 \mu \mathrm{g} / \mathrm{ml}$, respectively [12]. The plates were incubated at $28^{\circ} \mathrm{C}$ for $2-3$ days, then the colony-forming units (CFU) were calculated and colonial morphology was observed. Afterward, Ap-, Km-, and Tc-resistant colonies in different morphologies were selected and spread on fresh MAC plates with the other two antibiotics.

\section{Strain Identification}

The $\mathrm{Ap}^{\mathrm{r}}, \mathrm{Km}^{\mathrm{r}}$, and $\mathrm{Tc}^{\mathrm{r}}$ strains were cultured on LA plates and identified for carbohydrate utilization capability using API $50 \mathrm{CH}$ and API RAPID ID 32A kits (bioMérieux).

\section{Results}

Water Sample Inspection

To know drug resistance of intestinal bacteria in the four major waterways, water samples were collected from

Table 1. Bacterial antibiotic-resistance and lactose fermentation capability in four major rivers in Taichung.

\begin{tabular}{|c|c|c|c|c|c|c|c|c|c|c|}
\hline \multirow{3}{*}{ No. } & \multirow{3}{*}{$\begin{array}{c}\text { Aquatic } \\
\text { environment }^{I}\end{array}$} & \multirow{2}{*}{\multicolumn{2}{|c|}{$\begin{array}{l}\text { MAC plates without } \\
\text { antibiotics }(\mathrm{CFU} / \mathrm{ml})^{2}\end{array}$}} & \multicolumn{6}{|c|}{ MAC plates with antibiotic (CFU/ml) } & \multirow{3}{*}{$\begin{array}{c}\text { Water } \\
\mathrm{pH}\end{array}$} \\
\hline & & & & \multicolumn{2}{|c|}{ Ampicillin (Ap) } & \multicolumn{2}{|c|}{ Kanamycin (Km) } & \multicolumn{2}{|c|}{ Tetracycline $(\mathrm{Tc})$} & \\
\hline & & VCGB & LFIB & VCGB & LFIB & VCGB & LFIB & VCGB & LFIB & \\
\hline 1 & Lu-ur & 15,200 & $\begin{array}{c}8,400 \\
(55.3 \%)\end{array}$ & 360 & $\begin{array}{c}200 \\
(1.3 \%)\end{array}$ & 50 & $\begin{array}{c}50 \\
(0.3 \%)\end{array}$ & 325 & $\begin{array}{c}325 \\
(2.1 \%)\end{array}$ & 7.0 \\
\hline 2 & Lu-mr & 56,600 & $\begin{array}{c}6,800 \\
(12.0 \%)\end{array}$ & 1,320 & $\begin{array}{c}290 \\
(0.5 \%)\end{array}$ & 925 & $\begin{array}{c}725 \\
(1.3 \%)\end{array}$ & 1,675 & $\begin{array}{c}1,475 \\
(2.6 \%)\end{array}$ & 7.2 \\
\hline 3 & Lu-lr & 12,200 & $\begin{array}{c}9,000 \\
(73.8 \%) \\
\end{array}$ & 360 & $\begin{array}{c}180 \\
(1.5 \%) \\
\end{array}$ & 475 & $\begin{array}{c}475 \\
(3.9 \%) \\
\end{array}$ & 400 & $\begin{array}{c}400 \\
(3.3 \%) \\
\end{array}$ & 7.1 \\
\hline 4 & Li- ur & 44,400 & $\begin{array}{l}30,800 \\
(69.4 \%)\end{array}$ & 510 & $\begin{array}{c}270 \\
(0.6 \%)\end{array}$ & 3,635 & $\begin{array}{l}3,375 \\
(7.6 \%)\end{array}$ & 2,750 & $\begin{array}{c}2,450 \\
(5.5 \%)\end{array}$ & 7.1 \\
\hline 5 & Li- mr & 31,000 & $\begin{array}{c}3,600 \\
(11.6 \%)\end{array}$ & 1,020 & $\begin{array}{c}20 \\
(0.1 \%)\end{array}$ & 700 & $\begin{array}{c}450 \\
(1.5 \%)\end{array}$ & 275 & $\begin{array}{c}250 \\
(0.8 \%)\end{array}$ & 7.2 \\
\hline 6 & $\mathrm{Li}-\mathrm{lr}$ & 6,760 & $\begin{array}{c}3,460 \\
(51.2 \%)\end{array}$ & 2,320 & $\begin{array}{c}900 \\
(13.3 \%)\end{array}$ & 180 & $\begin{array}{c}90 \\
(1.3 \%) \\
\end{array}$ & 390 & $\begin{array}{c}360 \\
(5.3 \%)\end{array}$ & 7.2 \\
\hline 7 & Me-ur & 21,800 & $\begin{array}{c}16,600 \\
(76.1 \%)\end{array}$ & 590 & $\begin{array}{c}400 \\
(1.8 \%)\end{array}$ & 125 & $\begin{array}{c}75 \\
(0.3 \%)\end{array}$ & 1,050 & $\begin{array}{c}825 \\
(3.8 \%)\end{array}$ & 7.3 \\
\hline 8 & Me-mr & 17,600 & $\begin{array}{c}14,400 \\
(81.8 \%)\end{array}$ & 820 & $\begin{array}{c}600 \\
(3.4 \%)\end{array}$ & 1,375 & $\begin{array}{l}1,100 \\
(6.3 \%)\end{array}$ & 2,125 & $\begin{array}{c}1,925 \\
(10.9 \%)\end{array}$ & 7.3 \\
\hline 9 & Me-lr & 11,200 & $\begin{array}{c}6,000 \\
(53.6 \%)\end{array}$ & 290 & $\begin{array}{c}70 \\
(0.6 \%)\end{array}$ & 300 & $\begin{array}{c}275 \\
(2.5 \%)\end{array}$ & 550 & $\begin{array}{c}550 \\
(4.9 \%)\end{array}$ & 7.2 \\
\hline 10 & Ma-ur & 6,800 & $\begin{array}{c}4,800 \\
(70.6 \%) \\
\end{array}$ & 130 & $\begin{array}{c}70 \\
(1.0 \%) \\
\end{array}$ & 25 & $\begin{array}{c}25 \\
(0.4 \%) \\
\end{array}$ & 125 & $\begin{array}{c}125 \\
(1.8 \%)\end{array}$ & 7.2 \\
\hline 11 & Ma-mr & 54,800 & $\begin{array}{c}40,200 \\
(73.4 \%)\end{array}$ & 1,540 & $\begin{array}{c}1,160 \\
(2.1 \%)\end{array}$ & 1,100 & $\begin{array}{c}950 \\
(1.7 \%)\end{array}$ & 3,425 & $\begin{array}{c}3,125 \\
(5.7 \%)\end{array}$ & 7.2 \\
\hline 12 & Ma-lr & 8,200 & $\begin{array}{c}6,400 \\
(78.0 \%)\end{array}$ & 160 & $\begin{array}{c}100 \\
(1.2 \%)\end{array}$ & 125 & $\begin{array}{c}100 \\
(1.2 \%)\end{array}$ & 250 & $\begin{array}{c}200 \\
(2.4 \%)\end{array}$ & 7.1 \\
\hline
\end{tabular}

${ }^{l} \mathrm{Lu}, \mathrm{Li}, \mathrm{Me}$ and Ma represent Luchuan, Liuchuan, Meichuan and Mayuantou, respectively; ur, $\mathrm{mr}$ and $\mathrm{lr}$ represent upper reach, middle reach and lower reach, respectively.

${ }^{2}$ MAC, MacConkey; VCGB, Viable Count of Gram-negative Bacteria; LFIB, Lactose-Fermenting Intestinal Bacteria. 
Supplemental Table 1. Types of colony appearance and antibiotic resistance patterns of LFIB in various reaches of rivers.

\begin{tabular}{|c|c|c|c|c|c|}
\hline \multirow[t]{2}{*}{ No } & \multirow{2}{*}{$\begin{array}{l}\text { Aquatic } \\
\text { environ- } \\
\text { ment }\end{array}$} & \multirow[t]{2}{*}{ Colony patterns* } & \multicolumn{3}{|c|}{$\begin{array}{l}\text { Drug-resistance } \\
\text { patterns }\end{array}$} \\
\hline & & & Ap & $\mathrm{Km}$ & $\mathrm{Tc}$ \\
\hline 1 & Lu-ur & A-1,A-2,A-4,B-1 & $\begin{array}{l}\mathrm{R} \\
\mathrm{R} \\
\mathrm{R} \\
\mathrm{S}\end{array}$ & $\begin{array}{l}\mathrm{S} \\
\mathrm{S} \\
\mathrm{R} \\
\mathrm{S}\end{array}$ & $\begin{array}{l}\mathrm{S} \\
\mathrm{R} \\
\mathrm{R} \\
\mathrm{S}\end{array}$ \\
\hline 2 & Lu-mr & $\begin{array}{l}\text { A-1,A-2,A-4,B-2 } \\
\text { C-1,D-1,E-1,F-1 }\end{array}$ & $\begin{array}{l}\mathrm{R} \\
\mathrm{R} \\
\mathrm{R} \\
\mathrm{S}\end{array}$ & $\begin{array}{l}\mathrm{S} \\
\mathrm{S} \\
\mathrm{R} \\
\mathrm{S}\end{array}$ & $\begin{array}{l}\mathrm{S} \\
\mathrm{R} \\
\mathrm{R} \\
\mathrm{S}\end{array}$ \\
\hline 3 & Lu-lr & $\begin{array}{c}\text { A-1,A-2,A-4,B-1, } \\
\text { B-2,F-1 }\end{array}$ & $\begin{array}{l}\mathrm{R} \\
\mathrm{R} \\
\mathrm{R} \\
\mathrm{S}\end{array}$ & $\begin{array}{l}\mathrm{S} \\
\mathrm{S} \\
\mathrm{R} \\
\mathrm{S}\end{array}$ & $\begin{array}{l}\mathrm{S} \\
\mathrm{R} \\
\mathrm{R} \\
\mathrm{S}\end{array}$ \\
\hline 4 & Li- ur & $\begin{array}{c}\text { A-1,A-2,A-4,A-5, } \\
\text { B-1,F-1 }\end{array}$ & $\begin{array}{l}\mathrm{R} \\
\mathrm{R} \\
\mathrm{R} \\
\mathrm{S}\end{array}$ & $\begin{array}{l}\mathrm{S} \\
\mathrm{S} \\
\mathrm{R} \\
\mathrm{S}\end{array}$ & $\begin{array}{l}\mathrm{S} \\
\mathrm{R} \\
\mathrm{R} \\
\mathrm{S}\end{array}$ \\
\hline 5 & Li- mr & $\begin{array}{c}\text { A-1,A-2,A-3,A-5, } \\
\text { B-1,E-1,F-1 }\end{array}$ & $\begin{array}{l}\mathrm{R} \\
\mathrm{R} \\
\mathrm{R} \\
\mathrm{S}\end{array}$ & $\begin{array}{l}\mathrm{S} \\
\mathrm{S} \\
\mathrm{R} \\
\mathrm{S}\end{array}$ & $\begin{array}{l}\mathrm{S} \\
\mathrm{R} \\
\mathrm{R} \\
\mathrm{S}\end{array}$ \\
\hline 6 & $\mathrm{Li}-\mathrm{lr}$ & $\begin{array}{c}\text { A-1,A-2,A-3,B-2, } \\
\text { C-1,D-1,E-1,F-1 }\end{array}$ & $\begin{array}{l}\mathrm{R} \\
\mathrm{R} \\
\mathrm{R} \\
\mathrm{S}\end{array}$ & $\begin{array}{l}\mathrm{S} \\
\mathrm{S} \\
\mathrm{R} \\
\mathrm{S}\end{array}$ & $\begin{array}{l}\mathrm{S} \\
\mathrm{R} \\
\mathrm{R} \\
\mathrm{S}\end{array}$ \\
\hline 7 & Me-ur & $\begin{array}{c}\text { A-1,A-2,A-3,B-1, } \\
\text { F-1 }\end{array}$ & $\begin{array}{l}\mathrm{R} \\
\mathrm{R} \\
\mathrm{R} \\
\mathrm{S} \\
\mathrm{S}\end{array}$ & $\begin{array}{l}\mathrm{S} \\
\mathrm{R} \\
\mathrm{S} \\
\mathrm{S} \\
\mathrm{S}\end{array}$ & $\begin{array}{l}\mathrm{S} \\
\mathrm{S} \\
\mathrm{R} \\
\mathrm{R} \\
\mathrm{S}\end{array}$ \\
\hline 8 & Me-mr & $\begin{array}{c}\text { A-1,A-2,A-3,B-2, } \\
\text { C-1,D-1,F-1 }\end{array}$ & $\begin{array}{l}\mathrm{R} \\
\mathrm{R} \\
\mathrm{R} \\
\mathrm{R} \\
\mathrm{S}\end{array}$ & $\begin{array}{l}\mathrm{S} \\
\mathrm{R} \\
\mathrm{S} \\
\mathrm{R} \\
\mathrm{S}\end{array}$ & $\begin{array}{l}\mathrm{S} \\
\mathrm{S} \\
\mathrm{R} \\
\mathrm{R} \\
\mathrm{S}\end{array}$ \\
\hline 9 & Me-lr & $\begin{array}{c}\text { A-1,A-2,A-4,B-2, } \\
\text { C-1,D-1,E-1,F-1, } \\
\text { G-1,H-1 }\end{array}$ & $\begin{array}{l}\mathrm{R} \\
\mathrm{R} \\
\mathrm{R} \\
\mathrm{S}\end{array}$ & $\begin{array}{l}\mathrm{S} \\
\mathrm{S} \\
\mathrm{R} \\
\mathrm{S}\end{array}$ & $\begin{array}{l}\mathrm{S} \\
\mathrm{R} \\
\mathrm{R} \\
\mathrm{S}\end{array}$ \\
\hline 10 & Ma-ur & $\begin{array}{c}\text { A-1,A-2,B-2,C-1, } \\
\text { D-1,F-1,H-1 }\end{array}$ & $\begin{array}{l}\mathrm{R} \\
\mathrm{R} \\
\mathrm{R} \\
\mathrm{R} \\
\mathrm{S}\end{array}$ & $\begin{array}{l}\mathrm{S} \\
\mathrm{R} \\
\mathrm{S} \\
\mathrm{R} \\
\mathrm{S}\end{array}$ & $\begin{array}{l}\mathrm{S} \\
\mathrm{S} \\
\mathrm{R} \\
\mathrm{R} \\
\mathrm{S}\end{array}$ \\
\hline 11 & Ma-mr & $\begin{array}{c}\text { A-1,A-2,A-4,B-2, } \\
\text { C-1,D-1,F-1,G-1, } \\
\text { H-1 }\end{array}$ & $\begin{array}{l}\mathrm{R} \\
\mathrm{R} \\
\mathrm{R} \\
\mathrm{S}\end{array}$ & $\begin{array}{l}\mathrm{S} \\
\mathrm{S} \\
\mathrm{R} \\
\mathrm{S}\end{array}$ & $\begin{array}{l}\mathrm{S} \\
\mathrm{R} \\
\mathrm{R} \\
\mathrm{S}\end{array}$ \\
\hline 12 & Ma-lr & $\begin{array}{c}\mathrm{A}-1, \mathrm{~A}-2, \mathrm{~A}-3, \mathrm{C}-1, \\
\mathrm{D}-1\end{array}$ & $\begin{array}{l}\mathrm{R} \\
\mathrm{R} \\
\mathrm{R} \\
\mathrm{R} \\
\mathrm{S}\end{array}$ & $\begin{array}{l}\mathrm{S} \\
\mathrm{R} \\
\mathrm{S} \\
\mathrm{R} \\
\mathrm{S}\end{array}$ & $\begin{array}{l}\mathrm{S} \\
\mathrm{S} \\
\mathrm{R} \\
\mathrm{R} \\
\mathrm{S}\end{array}$ \\
\hline
\end{tabular}

*colony pattern code:

\begin{tabular}{|l|l|}
\hline Form, margin and surface of colony & Elevation \\
\hline A: circular, entire, smooth & \\
B: circular, entire, concentric & 1: flat \\
C: circular, lobate, wrinkled & $2:$ convex \\
D: circular, serrated, contoured & $3:$ raised \\
E: irregular, undulate, wrinkled & $4:$ crateriform \\
F: circular, erose, punctiform & 5: umbonate \\
G: filamentous & \\
H: rhizoid & \\
\hline
\end{tabular}

the monitoring stations of the Taichung Environmental Protection Bureau, which represent the upper, middle, and lower reaches of each measured waterway (Fig. 1). The samples collected were cultured in MAC medium with or without antibiotics.

As shown in Table 1, $\mathrm{pH}$ value of the water from the four waterways ranged between 7.0 and 7.3. In the upper reach of Luchuan Canal the viable count of the Gram-negative bacteria (VCGB) was about $15,200 \mathrm{CFU} / \mathrm{ml}$; the lactose-fermenting intestinal bacteria (LFIB), as evidenced by the ability to ferment a lactoseforming red colony on a MAC plate, accounted for about $55.3 \%$; and four types of colony morphology were observed. The VCGB in the middle reach of Luchuan Canal was about 56,600 CFU/ml, the LFIB accounted for about $12 \%$, and there were eight types of colony morphology. The VCGB in the lower reach was about $12,200 \mathrm{CFU} / \mathrm{ml}, 73.8 \%$ of which were LFIB, and there were six types of colony morphology (Supplemental Table 1).

The VCGB in the upper reach of Liuchuan Canal was about 44,400 CFU/ml, the LFIB accounted for about $69.4 \%$, and there were six types of colony morphology. The VCGB in the middle reach was about $31,000 \mathrm{CFU} /$ $\mathrm{ml}, 11.6 \%$ of which were LFIB. There were seven types of colony appearance. The Gram-negative bacteria content in the lower reach was about $6,760 \mathrm{CFU} / \mathrm{ml}$, LFIB accounted for about $51.2 \%$, and there were eight types of colony appearance. The VCGB in the lower reach of Liuchuan Canal was lower than that in the upper or middle reach, but the LFIB in the middle reach were apparently less than that in the upper and lower reaches (Table 1, Supplemental Table 1).

The VCGB in the upper reach of Meichuan Canal was about 21,800 CFU/ml, LFIB accounted for about 76.1\%, and there were five types of colony appearance; the VCGB in the middle reach was about $17,600 \mathrm{CFU} / \mathrm{ml}$, the LFIB accounted for about $81.8 \%$, and there were seven types of colony appearance; and the VCGB in the lower reach was about 11,200 CFU/ml, the LFIB accounted for about $53.6 \%$, there were 10 types of colony appearance (Table 1 , Supplemental Table 1). 
In the upper reach of the Mayuantou River the VCGB was about $6,800 \mathrm{CFU} / \mathrm{ml}$ (70.6\% of which were LFIB), and seven types of colony appearance; the VCGB in the middle reach was about 54,800 CFU/ml, LFIB accounted for about $73.4 \%$, and there were nine types of colony appearance; and the VCGB in the lower reach was about $8,200 \mathrm{CFU} / \mathrm{ml}$, LFIB accounted for about $78 \%$, and there were five types of colony appearance (Table 1, Supplemental Table 1).

To know the drug resistance patterns, Ap-, Km-, and Tc-resistant colonies in different shapes were selected and spread on fresh MAC plates containing the other two antibiotics. The results showed that all water samples contained drug-resistant strains. Four drug resistance patterns $\left(\mathrm{Ap}^{\mathrm{r}}, \mathrm{Km}^{\mathrm{s}}, \mathrm{Tc}^{\mathrm{s}} ; \mathrm{Ap}^{\mathrm{r}}, \mathrm{Km}^{\mathrm{s}}, \mathrm{Tc}^{\mathrm{r}} ; \mathrm{Ap}^{\mathrm{r}}, \mathrm{Km}^{\mathrm{r}}, \mathrm{Tc}^{\mathrm{r}}\right.$; and $\mathrm{Ap}^{\mathrm{s}}, \mathrm{Km}^{\mathrm{s}}, \mathrm{Tc}^{\mathrm{s}}$ ) were detected in the eight water samples from the upper, middle, and lower reaches of Luchuan and Liuchuan canals, the lower reach of Meichuan Canal, and the middle reach of the Mayuantou. The other four water samples contained five drug resistance patterns. Ap ${ }^{\mathrm{r}}, \mathrm{Km}^{\mathrm{r}}$, $\mathrm{Tc}^{\mathrm{r}}$ strains were found in all water samples except for the upper reach of Meichuan Canal (Supplemental Table 1).

In the water samples from these four waterways, LFIB resistant to Ap, Km, and Tc ranged between $0.1 \%$ to $13.3 \%, 0.3 \%$ to $7.6 \%$, and $0.8 \%$ to $10.9 \%$, respectively. Among them, the $\mathrm{Ap}^{\mathrm{r}}$ or $\mathrm{Tc}^{\mathrm{r}}$ were higher than the $\mathrm{Km}^{\mathrm{r}}$; but in water samples from the lower reach of Luchuan Canal and upper reach of Liuchuan Canal, the bacterial count resistant to $\mathrm{Km}$ was apparently larger (Table 1).

\section{Identification of Multiple Drug-Resistant Strains}

Among the tested water samples, 11 contained $\mathrm{Ap}^{\mathrm{r}}, \mathrm{Km}^{\mathrm{r}}$, $\mathrm{Tc}^{\mathrm{r}}$ strains. Those with apparently different appearances were selected for strain identification according to the biochemical characteristic analysis. Results showed that there were six different $\mathrm{Ap}^{\mathrm{r}}, \mathrm{Km}^{\mathrm{r}}$, Tc $\mathrm{Cc}^{\mathrm{r}}$ strains, including three hydrophilic Aeromonas spp., plus Escherichia coli, Klebsiella, and Providencia stuartii. As shown in Table 2, six of the water samples contained more than one $\mathrm{Ap}^{\mathrm{r}}, \mathrm{Km}^{\mathrm{r}}, \mathrm{Tc}^{\mathrm{r}}$ strain.

\section{Discussion}

The values of water $\mathrm{pH}$ of the four rivers were maintained between 7.0 and 7.3, indicating that either few substances affecting the $\mathrm{pH}$ were discharged or the water volumes of the rivers were large enough to dilute the $\mathrm{pH}$ affecting inputs. Since growth of most bacteria is favored by $\mathrm{pH}$ values near 7.0, this may explain why high VCGB were detected in the samples.

Important conclusions of the experimental results:

Drug-resistant bacteria are ubiquitous in the four major Taichung waterways

As a result of the extensive application of antibiotics, bacterial resistance has become increasingly severe [13]. Relevant reports mostly lay emphasis on the places where the antibiotics are used in large quantities, such as hospitals, livestock farms, farms, and fish farms [14]. The wastewater discharged from these places is usually treated by three- to four-stage purification, including 1) pre-treatment: to remove massive suspended substances, heavy inorganic substances, and oil and fat; 2) primary treatment: to remove suspended substances, metals, and nutrient substances; 3) secondary treatment: to get rid of the organic substances, other impurities or fine suspended matters left in the sewage after primary treatment, including chlorination; and 4) tertiary treatment: to remove the residual water pollutants, such as nitrogen and phosphor eutrophication agents and chlorinated organic substances after the aforesaid procedures [15]. Without effective physical, chemical, and biological treatment, the detrimental materials, drugs, and microorganisms are definitely discharged into the soil or rivers in our living environment. The tested water samples in this study were from an open aquatic environment at 12 water monitoring stations along the rivers, covering the four major rivers in the center of Taichung. Drug-resistant strains were detected in all 12 water samples, with multiple resistant $\left(\mathrm{Ap}^{\mathrm{r}}, \mathrm{Km}^{\mathrm{r}}, \mathrm{Tc}^{\mathrm{r}}\right)$ strains being in all samples except one. These results show that the drug-resistant bacteria have existed in the rivers in urban areas universally, but related problems are seldom noticed or discussed.

Table 2. Distribution of multi-drug resistant bacteria in various reaches of rivers ${ }^{1}$.

\begin{tabular}{|c|c|c|c|c|c|c|c|c|c|c|c|c|}
\hline $\begin{array}{l}\text { Aquatic environment }^{2} \\
\text { Drug } \\
\text { resistant bacteria }\end{array}$ & Lu- ur & Lu- mr & $\mathrm{Lu}-1 \mathrm{r}$ & Li-ur & $\mathrm{Li}-\mathrm{mr}$ & $\mathrm{Li}-\mathrm{lr}$ & Me-ur & Me-mr & Me-lr & Ma-ur & Ma-mr & Ma-lr \\
\hline Escherichia & $+^{3}$ & + & + & - & - & - & - & - & - & - & + & + \\
\hline Klebsiella & - & - & - & + & + & - & - & - & - & - & + & + \\
\hline Providencia & - & - & - & + & - & - & - & - & - & - & - & - \\
\hline Aeromonas & + & + & + & - & - & + & - & + & + & + & + & - \\
\hline
\end{tabular}

${ }^{I}$ multi-drug resistant bacteria indicated the identified bacteria in this study resistant to ampicillin, kanamycin and tetracycline

${ }^{2}$ Abbreviation for each aquatic environment is the same as that mentioned in Table 1.

${ }^{3}+$, detected; - , non-detected 
Numbers of LFIB in the four major Taichung waterways are not correlated to VCGB

The results show that there is no positive correlation between the VCGB and the number of LFIB in the waterways. For example, the VCGB in the upper reach of Luchuan Canal was about 15,200 CFU/ml, 55.3\% of which were LFIB. In the middle canal reach, the VCGB increased by about 3.7 times $(56,600 \mathrm{CFU} / \mathrm{ml})$, but the proportion of LFIB decreased, which was $12 \%$ of the VCGB. In the lower canal reach, the VCGB decreased again (equivalent to that in the upper reach), but the proportion of LFIB was as high as $73.8 \%$ of the VCGB, and the Liuchuan Canal had similar conditions. Various factors might have resulted in different bacterial contents in the upper and lower reaches of river. When these open water courses pass through the city, there may be other water sources or sewage draining into them. In addition, sunshine, shade density, temperature, and oxygen content of different reaches may result in different river microbial ecologies [16].

Numbers of drug-resistant bacteria and drug resistance patterns in the four major Taichung waterways are not correlated to VCGB

The results showed that there is no correlation between the VCGB and the number of drug-resistant bacteria and drug resistance patterns in the water samples. This is not surprising, since the VCGB and the number of drug-resistant bacteria in the water samples may also be influenced by multiple complex natural and human factors, such as the ecological environment factors of illumination, temperature, and $\mathrm{pH}$, and exotics in the water area.

At least six drug resistance patterns are present in the four major Taichung waterways

The strains analyzed in this study have six drugresistance patterns: $\mathrm{Ap}^{\mathrm{r}}, \mathrm{Km}^{\mathrm{s}}, \mathrm{Tc}^{\mathrm{s}} ; \mathrm{Ap}^{\mathrm{s}}, \mathrm{Km}^{\mathrm{s}}, \mathrm{Tc}^{\mathrm{r}} ; \mathrm{Ap}^{\mathrm{r}}$, $\mathrm{Km}^{\mathrm{r}}, \mathrm{Tc}^{\mathrm{s}} ; \mathrm{Ap}^{\mathrm{r}}, \mathrm{Km}^{\mathrm{s}}, \mathrm{Tc}^{\mathrm{r}} ; \mathrm{Ap}^{\mathrm{r}}, \mathrm{Km}^{\mathrm{r}}, \mathrm{Tc}^{\mathrm{r}}$; and $\mathrm{Ap}^{\mathrm{s}}, \mathrm{Km}^{\mathrm{s}}, \mathrm{Tc}^{\mathrm{s}}$. The undetected drug resistance patterns are $\mathrm{Ap}^{\mathrm{s}}, \mathrm{Km}^{\mathrm{r}}, \mathrm{Tc}^{\mathrm{r}}$ and $\mathrm{Ap}^{\mathrm{s}}, \mathrm{Km}^{\mathrm{r}}$, $\mathrm{Tc}^{\mathrm{s}}$; the scarcest drug resistance pattern is $\mathrm{Ap}^{\mathrm{s}}, \mathrm{Km}^{\mathrm{s}}, \mathrm{Tc}^{\mathrm{r}}$ (only one strain from the Meichuan Canal upstream water sample is of this drug-resistance pattern).

Microorganisms resistant to the antibiotics Ap, $\mathrm{Km}$, and $\mathrm{Tc}$ in the four major Taichung waterways are primarily enteric bacilli

The strains resistant to all three antibiotics in the samples are E. coli, Klebsiella, Providencia stuartii, and Aeromonas, which are bacilli inhabiting animal and human intestinal tracts. The presence of large amounts of enteric bacilli in an aquatic environment indicates that the water source may have been polluted by feces. E. coli can cause such diseases as blood poisoning, urinary tract infection, and multiple enteric infections. Klebsiella is one of the important opportunistic pathogens and iatrogenic infectious bacteria causing pneumonia, blood poisoning, meningitis, liver abscess, urinary system infection, and renal abscess with high mortality rate [17]. P. stuartii can cause diarrhea and even bacteremias by contact infection and wound infection [18] in individuals with weakened immune systems. Aeromonas can cause diarrheal disease by consuming contaminated food, or wound infections by contact with contaminated water or soil [19-20].

The Aeromonas resistant to the antibiotics Ap, Km, and Tc can be detected in the four major waterways: the upper, middle, and lower reaches of Luchuan Canal; the lower reach of Liuchuan Canal; the middle and lower reaches of Meichuan Canal; and the upper reach and middle reaches of Mayuantou River. For immunocompromised persons, exposure to Aeromonas-contaminated water may cause infections in the endogenous blood, abdominal cavity, biliary tract, wounds, or the ureteral orifice [19]. Since an urban aquatic environment is in close contact with the local population, these water resources containing high numbers of drug-resistant strains are apparently hazardous to public health.

\section{Conclusions}

Foul sewers collect wastewater, separate solid pollutants from water, reduce the organic contaminants and eutrophic substances in water (nitrogen and phosphorous compounds), and decrease the hazard of sewage in the environment [15]. In the major European and Asian countries (Britain, Germany, the Netherlands, Singapore, etc.), the diffusion rate of public foul sewers is higher than $90 \%$ [21]. However, the diffusion rate of public foul sewers in Taiwan is only $36 \%$ [22], with Taichung having the lowest diffusion rate among five metropolitan areas, which is only $15.1 \%$ (Taipei City $100 \%$, New Taipei City $58 \%$, Kaohsiung City 50.5\%, Tainan City 20\%). Domestic sewage and partial industrial effluent are discharged directly without treatment into the rivers of Taichung, causing pollution. The increasingly severe bacterial resistance strongly indicates the necessity of building public foul sewers in urban areas of Taiwan, especially in Taichung. Besides increasing the diffusion rate of public foul sewers, some aquatic facilities may use a simple sewage filtration process to prevent partial sewage from flowing into the foul sewers, so as to reduce the sewage stream's load; and some aquatic facilities can be equipped with nano-film to block the contaminant source to some extent [23-24]. Currently, the best nano-film is capable of retaining virus particles effectively, allowing the water to flow through freely; or some aquatic facilities can conduct electrical current through a sodium chloride solution for electrolysis, so that the released chlorine can remove the bacteria in water effectively [25]. After all, the water area with safe water quality is the root of healthy and happy cities.

\section{Acknowledgements}

The authors would like to thank professor Juey-Wen Lin of National Chung Hsing University for technical advice and support. 


\section{References}

1. CHENG H.C. Willow River and Green River of Taichung that changes and development of the landscape. Ph. D thesis. National Taichung University of Education, Taichung, Taiwan, 2010 [In Chinese].

2. LAI S.H., ZENG L.T. Taichung City Government. History of Taichung City Development, 25, 1989 [In Chinese].

3. MINISTRY OF THE INTERIOR, R.O.C. (TAIWAN). Administrative area map in Tanzi Taichung, 2006 [In Chinese].

4. LU S.U. History of Taichung city names. Taiwan Historica, 1996 [In Chinese]

5. YIN Q.M. The regulation scheme of Liou-Chuan \& Tu-Ku \& Sia-Ciao-Zih-To \& Lyu-Chuan \& Da-Jhih drainage on Han-chi drainage system. Water Resources Agency, Taiwan, 2009 [In Chinese].

6. MISRA A. A river about to Die: Yamuna. Journal of Water Resource and Protection. 2, 489, 2010.

7. HUANG T.F. Environmental coexistent urban green living. Academic J Kang-Ning. 13, 1133, 2011.

8. BUSH K., COURVALIN P., DANTAS G., DAVIES J., EISENSTEIN B., HUOVINEN P., JACOBY G.A., KISHONY R., KREISWIRTH B.N., KUTTER E., et al. Tackling antibiotic resistance. Nat. Rev. Microbiol. 9, 894, 2011.

9. PORT J.A., CULLEN A.C., WALLACE J.C., SMITH M.N., FAUSTMAN E.M. Metagenomic frameworks for monitoring antibiotic resistance in aquatic environments. Environ. Health Perspect. 122, 222, 2014.

10. BAQUERO F., MARTONEZ J.L., CANTON R. Antibiotics and antibiotic resistance in water environments. Curr. Opin. Biotechnol. 19, 260, 2008.

11. HALLER L., AMEDEGNATO E., POTE J., WILDI W. Influence of freshwater sediment characteristics on persistence of fecal indicator bacteria. Water Air Soil pollution 203, 217, 2009.

12. BLATNY J.M., BRAUTASET T., WINTHER-LARSEN H.C., HAUGAN K., VALLA S. Construction and use of a versatile set of broad-host-range cloning and expression vectors based on the RK2 replicon. Appl. Environ. Microbiol. 2, 370, 1997.
13. FAIR R.J., TOR Y. Antibiotics and bacterial resistance in the $21^{\text {st }}$ century. Perspectives in medicinal chemistry. 6, 25, 2014.

14. MARSHALL B.M., LEVY S.B. Food animals and antimicrobials: impacts on human health. Clin. Microbiol. Rev. 24, 718, 2011.

15. VLASOPOULOS N., MEMON F.A., BUTLER D., MURPHY R. Life cycle assessment of wastewater treatment technologies treating petroleum process waters. Sci. Total. Environ. 1, 58, 2006.

16. FINKENBINE J.K., ATWATER J.W., MAVINIC D.S. Stream health after urbanization. JAWRA. 36, 1149, 2000.

17. BROBERG C.A., PALACIOS M., MILLER V.L. Klebsiella: a long way to go towards understanding this enigmatic jet-setter. F1000Prime Rep. 6, 64, 2014.

18. IDOWU O.J., ONIPEDE A.O., ORIMOLADE A.E., AKINYOOLA L.A., BABALOLA G.O. Extended-spectrum beta-lactamase orthopedic wound infections in Nigeria. J. Glob. Infect. Dis. 3, 211, 2011.

19. JANDA J.M., ABBOTT S.L. The genus Aeromonas: taxonomy, pathogenicity, and infection. Clin. Microbiol. Rev. 23, 35, 2010.

20. PIOTROWSKA M., POPOWSKA M. The prevalence of antibiotic resistance genes among Aeromonas species in aquatic environments. Ann. Microbiol. 64, 921, 2014.

21. IMD WORLD COMPETITIVENESS CENTER. The Word Competitiveness Year Book. Switzerland, 2012.

22. MINISTRY OF THE INTERIOR, R.O.C. (TAIWAN). The table of the statistics of the sewage treatment rate. Available at: http://www.cpami.gov.tw/chinese/index.php? option=com_content\&view=article\&id=9995\&Itemid $=53$. Accessed March 31, 2016.

23. GEHRKE I., GEISER A., SOMBORN-SCHULZ A. Innovations in nanotechnology for water treatment. Nanotechnol. Sci. Appl. 8, 1, 2015 [In Chinese].

24. VAN DER BRUGGEN B., VANDECASTEELE C. Removal of pollutants from surface water and groundwater by nanofiltration: overview of possible applications in the drinking water industry. Environ. Pollut. 122, 435, 2003.

25. BOYCE J.M. Modern technologies for improving cleaning and disinfection of environmental surfaces in hospitals. Antimicrob. Resist. Infect. Control. 5, 10, 2016. 
